\title{
Modeling Student Migration to Karnataka for Higher Education using Partial Least Square Structural Equation Model
}

\author{
*Sandeep Rao \\ **Veena Andini
}

\begin{abstract}
With increasing student migration for higher education to Karnataka, it is important to understand the reasons which influence the migrants. Studies have indicated various push and pull factors for migration. This paper identifies the pull factors using exploratory factor analysis such as career opportunities, value for education, brand equity, living conditions and others influencing student migration. Further, the paper develops a structural equation model using partial least square technique based on the factors explored. The research is based on primary data collected from students who migrated to Karnataka for higher education. The PLS-SEM model shows that job opportunities and academic progression are the main factors influencing the decision to migrate to Karnataka.
\end{abstract}

Key Words: Migration, Pull factors, Higher Education, PLS-SEM

**Sandeep Rao is a Commonwealth Doctoral Research Scholar in Finance at the Strathclyde Business School, University of Strathclyde, Glasgow, UK. His areas of research include Financial markets contagion and migration. He can be reached at sandeepkrao@outlook.com

*Dr. Veena Andini is Professor in Department of management studies, PES University, Bangalore. She has pursued her PhD in Supply Chain Management. She has to her credit eleven research papers published in peer reviewed national journals. She has presented several papers in national and international conferences. Her areas of research include Supply Chain Management, Project Management and Migration. She can be reached at veenaandini@gmail.com 


\section{Introduction}

Migration involves movement from one geographic boundary to another for temporary or permanent settlement. The migration could be for various purposes like better standard of living, seeking refuge, better job opportunities, education, marriage, natural disasters or wars. Specifically, the migration within the country is movement of people from one state to another (inter-state migration) for purposes of education or career opportunities. Various push and pull factors are responsible for the interstate migration like low wages in non-agricultural sector, agricultural unemployment and lack of employment opportunities (Veena \& Sandeep, 2017).

This paper focuses on interstate student migration for higher education from other Indian states to Karnataka. The south Indian state of Karnataka is one of the largest states in India, with an annual GSDP of Rupees 871,995 crores and a GDP of Rupees 12,165,481crore(2016-17) as per Directorate of Economics and Statistics, Government of Karnataka, encompasses a total land mass of $191,791 \mathrm{~km}^{2}$ and a population of $61,095,297(2011$ census). The state is known for its striving Information technology, Bio technology, Education and Medical sectors.

As per the 2011 census, 25,078,333 people migrated to Karnataka, of which 720,385 migrated for education as compared to 18,190 student migrants out of 1,862,289 total migrants in 2001 census.

Major economic urban growth magnets like Delhi, Mumbai (Maharashtra), Kolkata (West Bengal), Bangalore (Karnataka) attract most inter-state migrants from states like Bihar, Rajasthan, Madhya Pradesh, Chhattisgarh, Jharkhand and north eastern states which fare low on social and economic development indices.

The discouraging academic situation in one's home state no longer seems to be sufficient to keep youth from pursuing their degree elsewhere. In the past 10 years, 3.7 million students have moved from their native in order to pursue further education. Of the total 3.7 million migrants, 2.6 million were men and the remaining 1.1 million were women. Furthermore, 0.62 
million(17\%) youths moved to a different state whereas 1.68 million shifted to another district within the same state. Amongst all the states in the country, Karnataka received the largest numbers of migrants for education (0.18 million). On the other hand, Uttar Pradesh was the source to most number of migrants (0.11 million) (Chhapial, 2014).

The most important states from the perspective of migration for education are Delhi, Maharashtra, Karnataka, Uttar Pradesh, Bihar, Andhra Pradesh, Kerala, West Bengal and Rajasthan. Of these states, Delhi, Maharashtra, Karnataka are the main destinations (i.e. attracting migrants from other states) whereas Bihar, Uttar Pradesh, Kerala, Andhra Pradesh, West Bengal and Rajasthan are the main sources of migrants (Chandrasekhar and Sharma, 2014).

According to the 2009 Right to Education Act of the Indian constitution, schooling is free and compulsory for all children from the age of 6 to 14 years. The stages in the Indian education system can be classified into five broad categories - primary, secondary, higher secondary, under graduation and post graduation. These classifications are based on the age group of the student and the degree they are pursuing.

The stages of the education system in India are shown in figure 1.

Figure 1: Education system in India

\begin{tabular}{|c|}
\hline \multicolumn{1}{|c|}{$\begin{array}{c}\text { Primary School } \\
\text { First to Fifth Standard } \\
\text { (for 6 to 10 years old) }\end{array}$} \\
\hline $\begin{array}{c}\text { Secondary School } \\
\text { Sixth to tenth Standard } \\
\text { (for 11 to 16 years old) }\end{array}$ \\
\hline Higher Secondary \\
\hline Eleventh \& Twelfth Standard/ pre-university \\
(for 16 to 17 years old)
\end{tabular}




\section{Literature Review}

There are several migration models in literature such as Ravenstein Law of migration (Ravenstein, 1885), Lee's push-pull Model (Lee, 1966), Gravity model, Alonso's General theory of movement (Vries et.al, 2000), Intervening opportunity model, models linking environmental conditions (Perch-Nielsen et al., 2008; Black et al, 2011), which discuss the factors influencing the migration of people from one geographic location to another. Black et.al (2011), identified certain major factors driving migration which include economic factors, political factors, demographic factors, social and environmental factors.

There are two main streams of migration models, which are macro and micro models. The micro models of migration focus on the individual (or family) who is assumed to decide rationally regarding migration in order to maximise utility. Since the analysis in this paper focuses on the individual characteristics' (students and their immediate family) effect on migration for higher education, a micro framework is used for investigation.

Student migration is influenced by several factors. Literature supports various variables which influence students to migrate for purpose of higher education. A few of these factors include clear differences in income determinants between migrants and non-movers (Gries, et.al 2011), differentiation in education quality, education costs among states and quality of a state's institutions (Christal,1982; Bayer 1968,Lankford and Taylor,1971; Fenske et al 1972,1974).

According to Abbott and Schmid(1975), the quality factor is the main deciding determinant among undergraduates for interstate migration at major US universities. One more important factor in student migration is the availability of quality in private institutions (Lankford and Taylor, 1971).Migrant undergraduate students attending private institutions are higher than those attending public institutions (Gossman et al, 1968; Lankford and Taylor, 1971).

Gossman and his associates highlight a positive relationship between the lack of private institutions in origin states and the migration rate of students.Migrants are ready to pay higher tuition fee for institutions of higher repute according to Carbone (1973).Geographic mobility is higher for students with academic talents, high education goals and high family income (Ferris 1973; Fenske et al 1972).Geographic proximity also influences students migration according to Lankford and Taylor (1971). 
State population size is also of substantial importance (Gossman et al 1968). Some of the interstate migration barriers like admission and tuition policies such as restrictive admission requirements, quotas and higher non-resident tuition tend to restrain student interstate mobility (Ferris 1973, Carbone 1973). State educational policies influence students' interstate migration (Christal 1982).Fenske et al (1972) highlight the importance of scholarship facility available to migrants at the selected place of study. Ferris (1973) also found that scholarship availability was a pull factor for graduate students.

Some more determinants for student migration are qualifying admission score, per capita income ( Rushton\& Meltzer, 1981), availability of jobs, the influence of family members (Ishtiaque and Ullah, 2013), better climate, transport system, culture, employment opportunities (Thet, 2014). According to Baharun, et al., (2011), the learning environment is the most important determinant for migration, followed by political environment, concern for students, cost of education, facilities and location. Indonesian students' selection criteria constitute of five main factors cost, reputation, proximity, job prospects and parents. (Kusumawati, Yanamandram, \&Perera, 2010). Kusumwati et al. (2010) suggest that the reputation of the institution was the most significant parameter in influencing migration decisions.

As per Joseph and Ford (1997) degree program flexibility, academic reputation and prestige reflecting national and international recognition, physical aspects of the campus such as the quality of the infrastructure and services, career opportunities upon completion, location of the institution and the time required for the completion of the program are contributing factors for students' migration.Grades scored by the students are yet another factor influencing the migration(Braxton, 1990).

Teaching excellence is also one more important determinant of choice (Keskinen et al., 2008; Sidin, et al., 2003; Soutar\& Turner, 2002). Ciriaci and Muscio (2011) argue that research quality and employability upon graduation are positively related. A couple of studies show that demand for private universities tends to be at a higher level of price sensitivity than public ones(Bezmen\&Depken, 1998).

One more significant determinant factor is gender discrimination (Paulsen, 1990; McDonough, 1997). According to Baharun et al., (2011), women consider safety as the most important factor while men place more importance on scheduling and sporting activities. 
Academic quality, facilities, campus surroundings, and personal characteristics are the most important criteria for student selection of universities in Malaysia (Sidin, Hussin, S. \& Soon, T., 2003).In the selection of English-speaking colleges in Quebec, Canada, a reputation of the institution was one of the determinants (Isherwood, 1991).Teaching quality, staff qualification, medium of instruction, reputation and institutional image related to academic staff are another set of determinants (Tang, Tang \&Tang, 2004). Migration is higher in metros than non-metro areas (McLaughlin and Perman; Mills and Hazarika 2003).The importance of university prestige and population density on student migration is highlighted by Abbott and Schmid (1975). The percentage of $\mathrm{Ph} . \mathrm{D}$. qualified full-time faculty at the institution is also considered by(Edward A. Baryla, Jr. \& Douglas Dotterweich, 2001).

\section{Need for the study}

In developing countries, migration is taking place on a large scale, both at inter-state and intrastate level. Factors which contribute towards the improvement of the livelihood and opportunities for migrated labourers have already been studied. However, there are very few studies relating to the student migration for the purpose of job opportunities and academic progression upon completion of their higher education. Studying the factors that determine the student migration has gained prominence because the internal migration is leading to 'internal brain drain', resulting in regional imbalances.

\section{Objectives of the Study}

1. To explore the pull factors influencing students' migration to Karnataka

2. To construct a PLS SEM which explores the effects of pull factors on job opportunities, academic progression and entrepreneurship of students who migrate to Karnataka for higher education

\section{Limitations of the study}

1. Data is collected from all streams of higher education except medicine and related courses.

2. The sample is collected only from educational hubs in Karnataka like Bangalore, Manipal and Belgaum. 


\section{Research Methodology}

Mixed research design is used in this paper. Mixed research design focuses on collecting, analyzing and mixing the quantitative and qualitative data from one or several studies. The combination of the two approaches (figure 2) provides a better understanding of the research problem rather than each approach separately (Creswell \& Clark 2006).In this research, the data is collected using both approaches and the outcomes are incorporated in the overall analysis of the results. Quantitative researchers admit the importance of qualitative data as it contributes to quantitative research, and the qualitative researchers realize that reporting views of several respondents make it impossible to generalize the results to the wider population (Creswell \& Clark 2006).

Figure 2: Triangulation Design

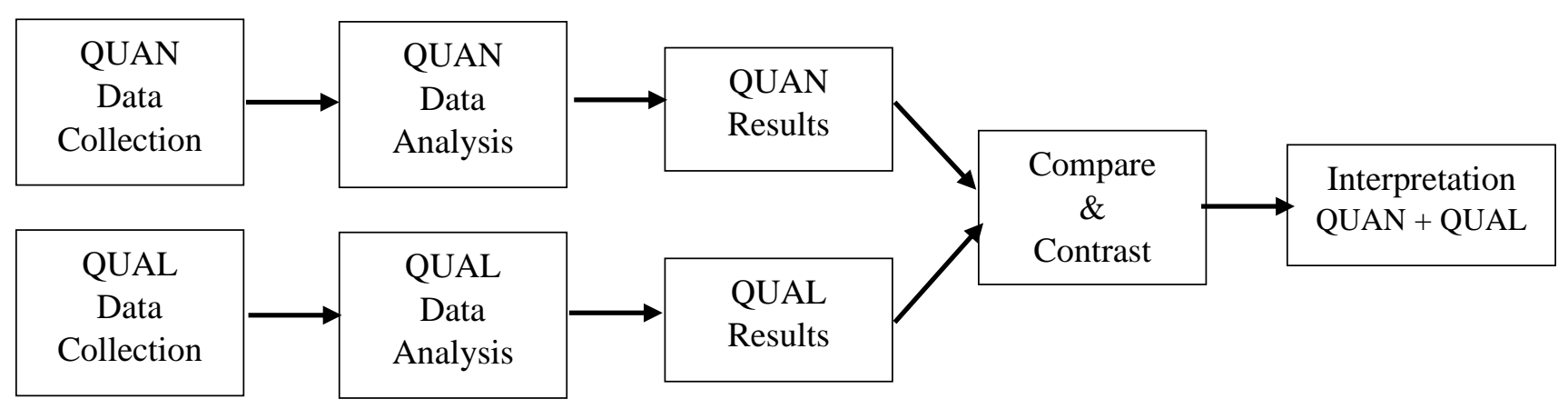

Source: Creswell \& Clark, (2006)

The study required both primary and secondary data. The primary data is collected with the help of a survey conducted in Karnataka. This research uses both quantitative and qualitative methods of data collection (triangular model, figure 2).

As part of qualitative research, a Focus Group Discussion (FGD) was conducted. This involved 25 students who migrated to Karnataka for pursuing higher education in different courses as shown in Table 1. These students were invited randomly from reputed institutes in Bangalore for exploring the determinants influencing them to migrate to Karnataka for higher education. The discussion was moderated by the researchers and the summary of the FGD is tabulated in table 1. 
Table1: Focused group discussion responses

\begin{tabular}{|c|c|c|c|c|c|}
\hline $\begin{array}{l}\text { Courses } \\
\text { pursuing/Migrated } \\
\text { from }\end{array}$ & North & East & West & South & Central \\
\hline Fashion Design & & $\begin{array}{l}\text { Cost effective, } \\
\text { No good } \\
\text { institutions in } \\
\text { native. }\end{array}$ & & & \\
\hline Polytechnic & $\begin{array}{l}\text { No good } \\
\text { institutions in } \\
\text { native, } \\
\text { Friends/ Seniors, } \\
\text { Promotion and } \\
\text { advertisements } \\
\text { by Karnataka }\end{array}$ & & & & \\
\hline $\begin{array}{l}\text { Mechanical } \\
\text { Engineering }\end{array}$ & & $\begin{array}{l}\text { Karnataka } \\
\text { universities are } \\
\text { famous for } \\
\text { education }\end{array}$ & & $\begin{array}{l}\text { More } \\
\text { companies in } \\
\text { Bangalore so } \\
\text { good jobs }\end{array}$ & \\
\hline MFA & Parental pressure & & $\begin{array}{l}\text { Getting seat in } \\
\text { good college } \\
\text { is difficult }\end{array}$ & & \\
\hline MBA & & $\begin{array}{l}\text { Good job } \\
\text { opportunity, Can } \\
\text { start own } \\
\text { business more } \\
\text { easily, Lot of } \\
\text { promotion and } \\
\text { advertisements } \\
\text { by Karnataka }\end{array}$ & & & \\
\hline $\begin{array}{l}\text { Mathematics\& } \\
\text { Physics }\end{array}$ & $\begin{array}{l}\text { Siblings studied } \\
\text { in Karnataka }\end{array}$ & & & & \\
\hline Psychology & & & & & $\begin{array}{l}\text { Weather is } \\
\text { good, } \\
\text { Karnataka } \\
\text { institutions } \\
\text { have good } \\
\text { systems in } \\
\text { place }\end{array}$ \\
\hline
\end{tabular}

Source: FGD

In order to collect quantitative data, a survey was carried out. During the survey, data is collected from the respondents by visiting different higher education institutes across Karnataka. The aim of the survey was to identify the most frequent reasons for student migration; what exactly they have been unhappy about with the higher education system in their native place and what are the parameters that they were looking for when choosing a place of higher study. 
The main objective of the study is to explore the preference of students for studying in Karnataka. Primary data was collected by conducting personal visits to colleges. The secondary data for the literature review is collected from EBSCO database, online sources and research reports on this topic.

As the 'population of interest' was very large, it was impossible to track all educational migrants in Karnataka due to the non-existence of a common database. A non-probability sampling technique was used for data collection. Depending on the nature of the sample, purposive sampling method was used. In purposive sampling, researcher chooses a certain group of people or place to study because it is known to be of a type that is desired. (McNeill \& Chapman, 2005). In purposive sampling, population elements are purposively selected and they are representative of the population of interest. They can offer the contributions sought for(Churchill Gilbert, 2009). The survey included both closed and open-ended questions, Likert-type responses and qualitative questions. The type of information collected through the survey included age, gender,

previous study details and current study details etc. A sample size of 364 (Rao's software) was planned. But, depending on the availability of respondents, data was collected from 360 respondents.

\section{Formulation of Questionnaire}

The survey used a questionnaire, which had both categorical and continuous variables. The responses were collected on multiple option questions and a five-point Likert scale ranging from 1 (Strongly disagree) to 5 (Strongly Agree). Five-point Likert scale being the simplest and easy to understand is suitable for this category of respondents.

\section{Results of Analysis}

The analysis of primary data has been carried out with the help of statistical tools, SPSS 21.0 and Smart PLS.

The paper adopts two-stage approach to conduct the multivariate analysis of the migration data. In the first stage, exploratory factor analysis (first generation technique) is adopted followed by the second-generation technique, partial least square structural equations model (PLS-SEM). 


\section{Stage One - Exploratory Factor Analysis}

Exploratory analysis is adopted to look for patterns in the data and establish the relationship between variables. It also helps in reduction of a large number of variables into the smaller set of factors. Factor analysis can be used when there is little or no prior knowledge on these relationships (Hair, et.al, 2014).

The first objective of the study is to analyze the pull factors influencing respondents (students residing outside Karnataka) to migrate to Karnataka for higher education. The survey used a questionnaire, which had fifty-four questions with a five-point Likert Scale ranging from 1 (Strongly Agree) to 5 (Strongly Disagree). The output of factor analysis is obtained by principal component analysis and specifying the rotation. The principal component analysis method is used to identify the number of factors that are to be extracted from the data using Promax rotation. The factors with factor loadings $\geq 0.60$ were considered as significant under each dimension. Six factors were restricted to this analysis.

Table 2 shows the output of Kaiser-Meyer-Olkin measure of sampling adequacy and Bartlett's test of sphericity. The KMO statistic varies between 0 and 1. Any value of KMO greater than 0.5 is preferred. Table 2 shows a KMO value of 0.911 which is greater than 0.5 . So, it can be inferred that factor analysis is appropriate for this dataset.

Table 2 : KMO and Bartlett's Test

\begin{tabular}{|c|c|c|}
\hline \multicolumn{2}{|c|}{ Kaiser-Meyer-Olkin Measure of Sampling Adequacy. } & 0.911 \\
\hline \multirow{3}{*}{ Bartlett's Test of Sphericity } & Approx. Chi-Square & 4201.676 \\
\hline & $\mathrm{df}$ & 561 \\
\hline & Sig. & 0.000 \\
\hline
\end{tabular}

A total of 6 factors namely Living (living conditions during education), Education (quality and structure of education), Career \& Placements (career and placement activities), Climate (conducive climatic conditions), Social Networking and Brand Equity were extracted. The cumulative variance was 51 percent in the model. Individual factor variances explained are 
28.812 percent, 5.982 percent, 5.285 percent, 3.936 percent, 3.589 percent and 3.220 percent. The result of the explanatory analysis revealed 15 significant items as shown in Table 3.

Table 3 : Pattern Matrix

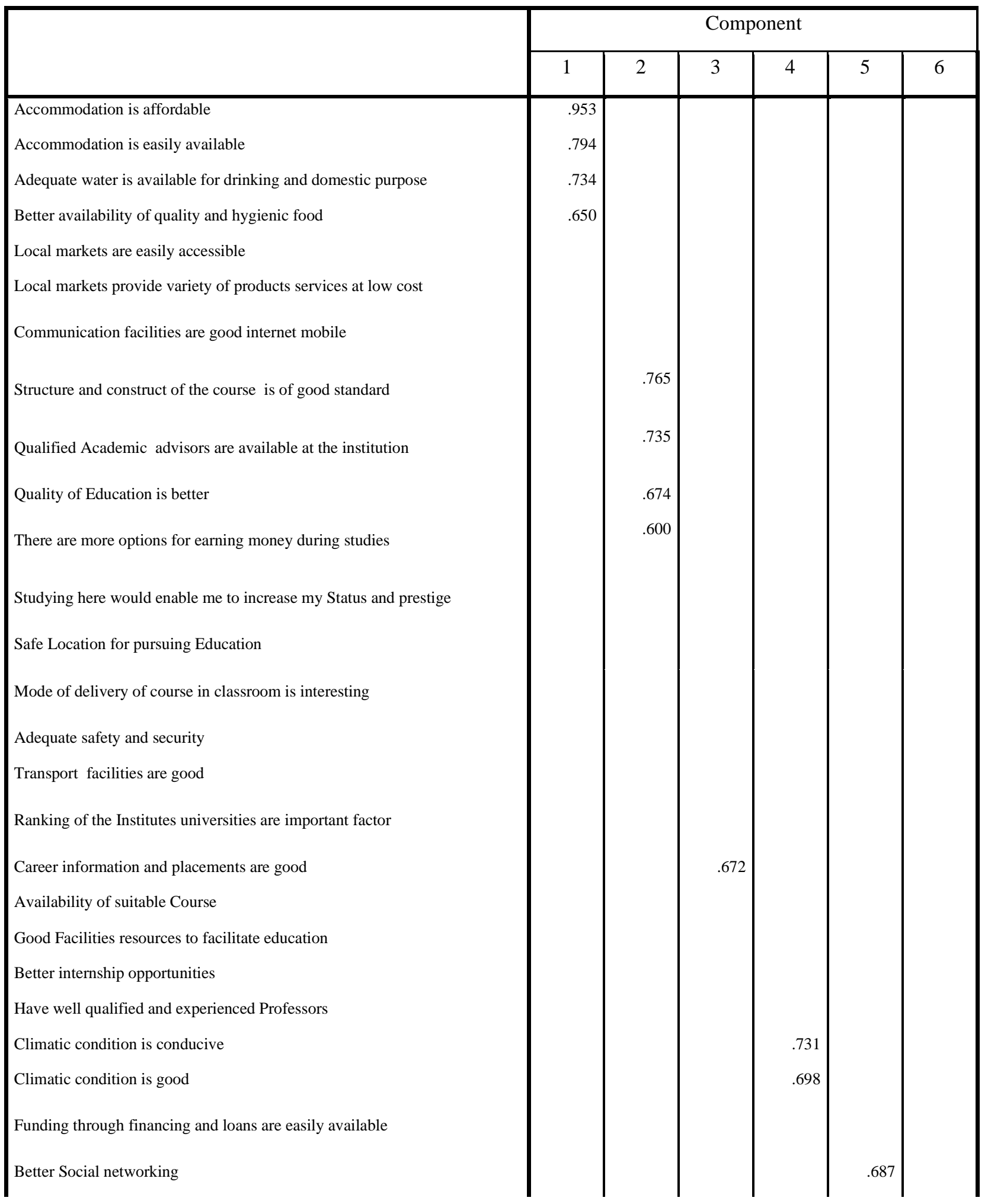




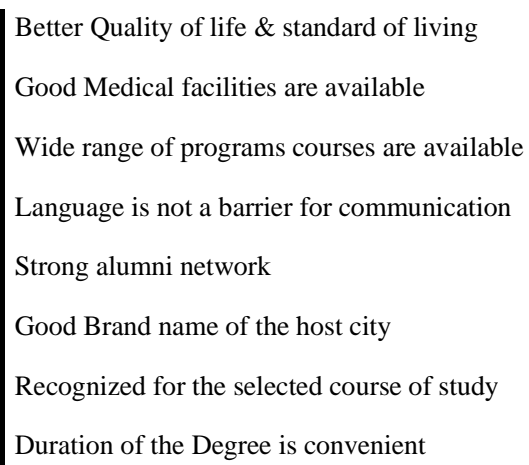

Table 4: Factor Reliability

\begin{tabular}{|c|c|c|c|}
\hline Factors & Items & Loading & Reliability \\
\hline \multirow{4}{*}{$\begin{array}{c}\text { Living } \\
\text { (Living } \\
\text { conditions } \\
\text { during } \\
\text { education) }\end{array}$} & Accommodation is affordable & .953 & \multirow{15}{*}{.808} \\
\hline & Accommodation is easily available & .794 & \\
\hline & Adequate water is available for drinking and domestic purpose & .734 & \\
\hline & Better availability of quality and hygienic food & .650 & \\
\hline \multirow{4}{*}{$\begin{array}{l}\text { Education } \\
\text { (Quality \& } \\
\text { Structure of } \\
\text { Education) }\end{array}$} & Structure and construct of the course is of good standard & .765 & \\
\hline & Qualified Academic advisors are available at the institution & .735 & \\
\hline & Quality of Education is better & .674 & \\
\hline & There are more options for earning money during studies & .600 & \\
\hline $\begin{array}{c}\text { Career \& } \\
\text { Placements } \\
\text { (activities) }\end{array}$ & Career information and placements are good at the institution & .672 & \\
\hline \multirow{2}{*}{$\begin{array}{l}\text { Climate } \\
\text { (conducive } \\
\text { climatic } \\
\text { conditions) } \\
\end{array}$} & Climatic condition is conducive & .731 & \\
\hline & Climatic condition is good & .698 & \\
\hline $\begin{array}{c}\text { Social } \\
\text { Networking }\end{array}$ & Better Social networking & .687 & \\
\hline \multirow{3}{*}{ Brand Equity } & Strong alumni network at the institution in Karnataka & .783 & \\
\hline & Good Brand name of the host city of Karnataka & .757 & \\
\hline & The institute is recognized for the selected course of study in & .656 & \\
\hline
\end{tabular}

Table 4 shows that Cronbach's alpha is 0.808. Cronbach alpha values are dependent on the number of items in the scale and a minimum level of 0.7 is preferred for good internal consistency (Nunnally, 1994). This shows there is high internal consistency among all 15 items. 


\section{Hypotheses for the Study}

Having conducted the literature review, gathering inputs from the focused group discussion and determining the factors from exploratory factor analysis, the following hypotheses are formulated to test whether the factors identified in the exploratory analysis have any significant influence on the objectives of this study which is to establish a relationship path between the factors and the reasons for students to migrate to Karnataka for higher education

The following are the proposed Hypotheses

H1: Living conditions during education has a positive effect on Value derived from Education H2: Conducive climatic conditions during education has a positive effect on academic progression

H3: Brand Equity has a positive effect on Value from Education

H4: Quality and Structure of Education has a positive effect on Value from Education

H5: Quality and Structure of Education has a positive effect on academic progression

H6: Social Networking has a positive effect on Academic progression

H7: Social Networking has a positive effect on Job opportunities

H8: Career \& placements activities has a positive effect on Job opportunities

H9: Academic progression has a positive effect on Job opportunities

H10: Academic progression has a positive effect on Entrepreneurship opportunities

H11: Job opportunities has a positive effect on Entrepreneurship opportunities

\section{Stage two - PLS-SEM}

PLS-SEM (PLS Path modeling) is a second-generation technique primarily used for exploratory research. This technique uses the variance among the dependent variables whereas the CB-SEM (Covariance based SEM) is a confirmatory technique using covariance among variables to confirm the proposed theory. 
In this paper the PLS-SEM process shown in Hair, et.al (2014) is followed. Accordingly, the PLS Path diagram proposed includes ten reflective latent variables. The indicator loadings are tested in the measurement model and path coefficients are tested in the structural model for reliability, validity and significance. Results are interpreted and conclusion about the PLS-SEM model is provided.

PLS-SEM involves specifying the path model that illustrates the hypothesis showing the relationship between the variables which will be examined. PLS-SEM starts with specifying the structural model. The Latent variables in the structural model are Living (LI), Climate (CI), Brand Equity (BE), Education (ED), Social networking (SN), Career \& Placements (CP), Value from Education(VE), Academic Progression (AP), Job Opportunities (JO) and Entrepreneurship opportunities (EO). The causal links between the latent variables are shown in the structural model (figure 3).

Living, Climate, Brand Equity, Education, Social networking, Career \& Placements are the exogenous variables, whereas the latent variables Value from Education, Academic Progression, Job Opportunities and Entrepreneurship opportunities are endogenous.

Figure 3: Structural Path Model

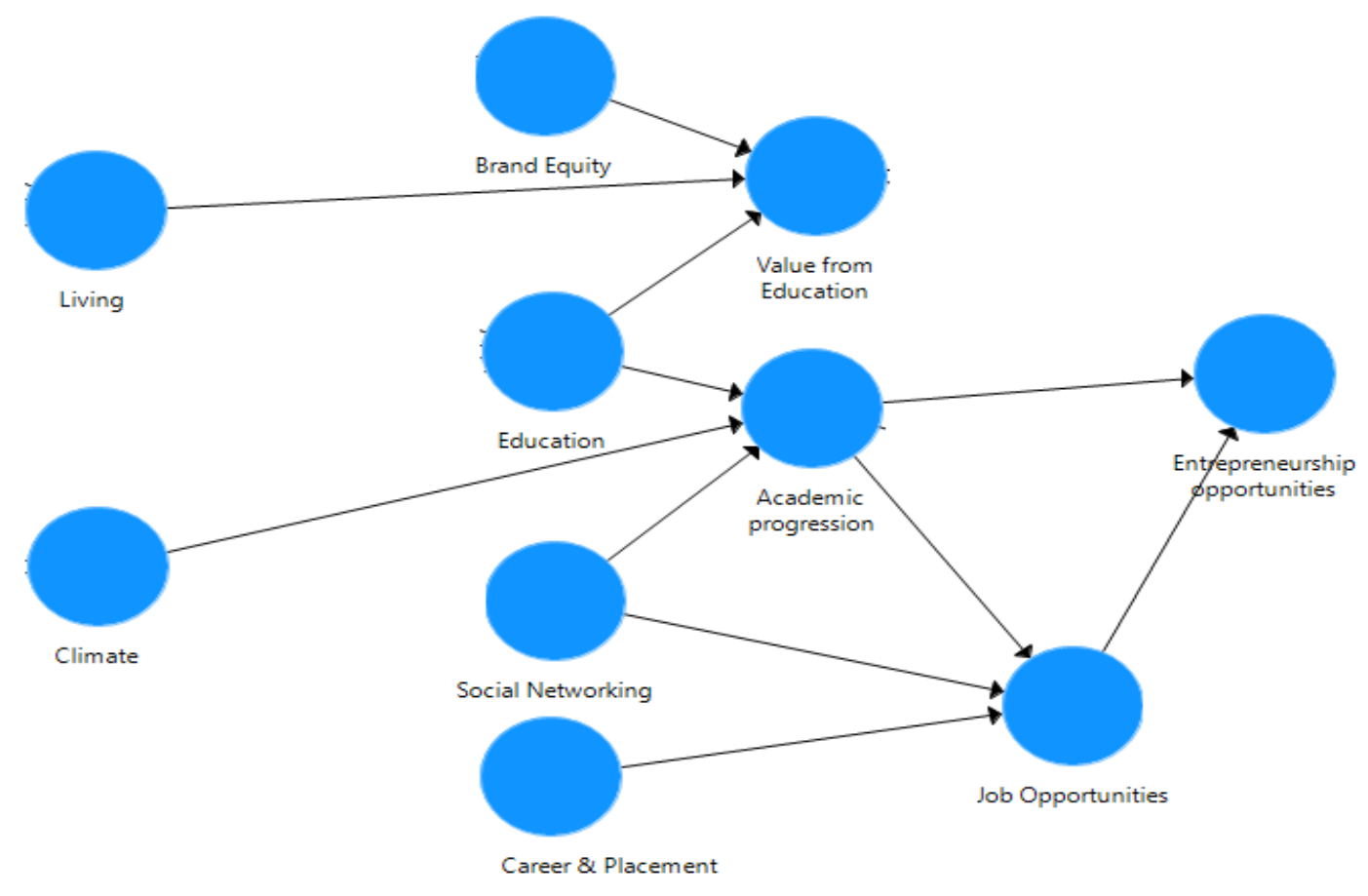


The reflective measurement model is specified and the respective indicators for each construct are identified (Figure 4) and coded (Table 5). The indicators and proposed relationships between constructs are based on the literature reviewed.

Figure4: Reflective Measurement Model

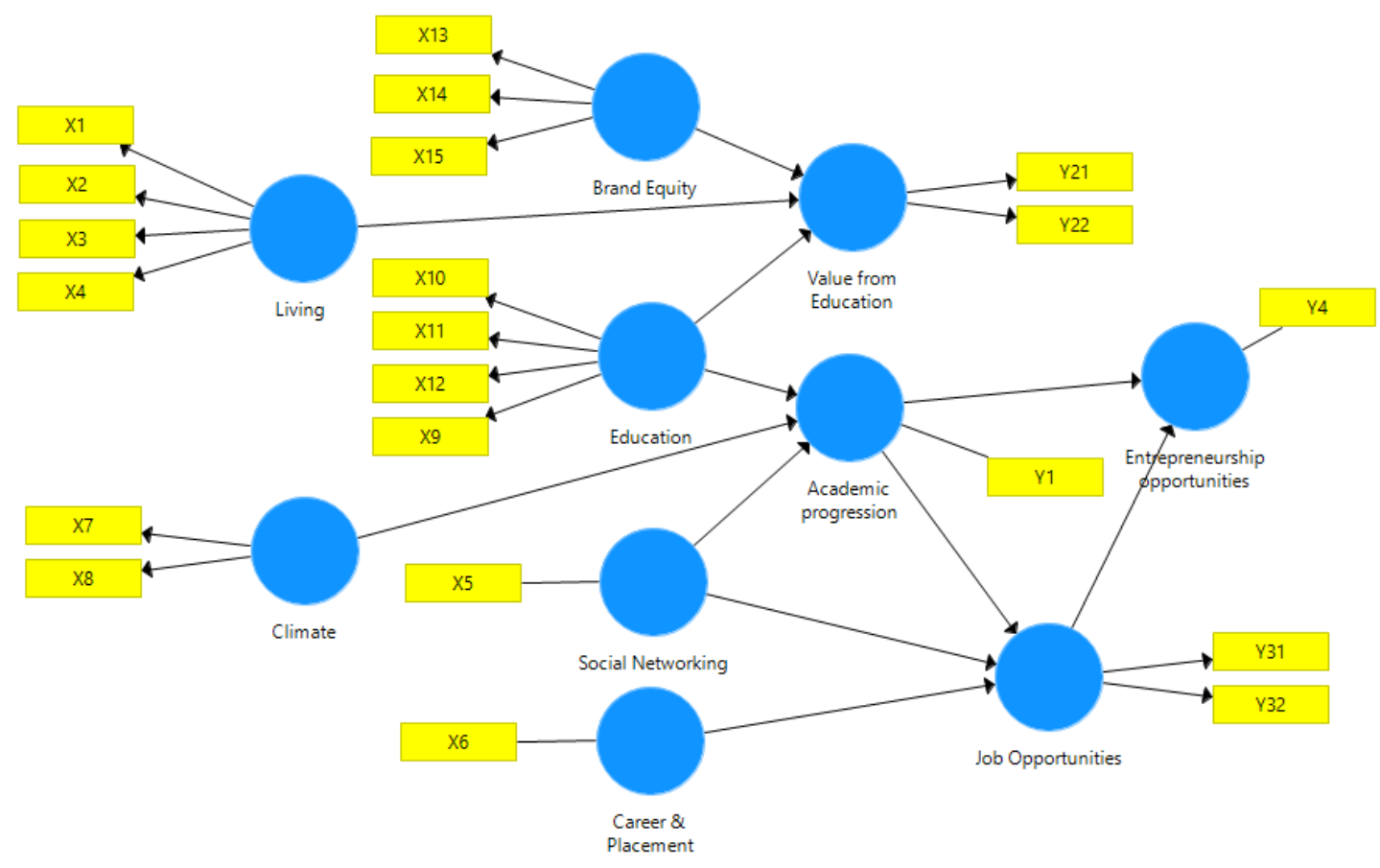

Table 5: Codes for the various indicators

\begin{tabular}{|l|c|}
\hline Accommodation is affordable & $\mathrm{X} 1$ \\
\hline Accommodation is easily available & $\mathrm{X} 2$ \\
\hline Adequate water is available for drinking and domestic purpose & $\mathrm{X} 3$ \\
\hline Better availability of quality and hygienic food & $\mathrm{X} 4$ \\
\hline Better Social networking & $\mathrm{X} 5$ \\
\hline Career information and placements are good & $\mathrm{X} 6$ \\
\hline Climatic condition is conducive & $\mathrm{X} 7$ \\
\hline Climatic condition is good & $\mathrm{X} 8$ \\
\hline Qualified Academic advisors are available & $\mathrm{X} 9$ \\
\hline Quality of Education is better & $\mathrm{X} 10$ \\
\hline Structure and construct of the course is of good standard & $\mathrm{X} 11$ \\
\hline There are more options for earning money during studies & $\mathrm{X} 12$ \\
\hline Recognized for the selected course of study & $\mathrm{X} 13$ \\
\hline Strong alumni network & $\mathrm{X} 14$ \\
\hline Good Brand name of the host city & $\mathrm{X} 15$ \\
\hline Academic progression prospects are better & $\mathrm{Y} 1$ \\
\hline
\end{tabular}




\begin{tabular}{|l|c|} 
Studying here would enable me to increase my Status and prestige & Y21 \\
\hline Total Earnings after Education is higher than total education expenses & Y22 \\
\hline After studying here there is better career opportunity & Y31 \\
\hline Better Job prospects after completion of Education & Y32 \\
\hline Opportunity for Entrepreneurship is good & Y4 \\
\hline
\end{tabular}

To determine the minimum sample size'10 times rule' (Barclay, Higgins, \& Thompson, 1995) is applied. In the model proposed, the largest number of paths directed at any latent variable is three, therefore as per the rule a minimum of 30 sample size is required. A total of 360 samples were collected, of which three were having suspicious pattern of responses and five had missing data, therefore eight records were deleted. The total sample size used for analysis was 352. PLSSEM being a non-parametric statistical method does not require the data to be distributed normally, however as a general guideline it is better to test whether the data is not too nonnormal (Hair, et.al, 2014). The data was tested for skewness and kurtosis and found to lie in the range of -1 to +1 indicating normality of data.

The PLS algorithm was run using the path weighting scheme, 300 iterations with stop criteria of 0.0000001 . The maximum number of 300 iterations with stop criterion of 0.00001 is required to ensure convergence (Henseler, 2010).Figure 5 shows the estimated indicator values of the measurement model.

Figure 5: Measurement Model

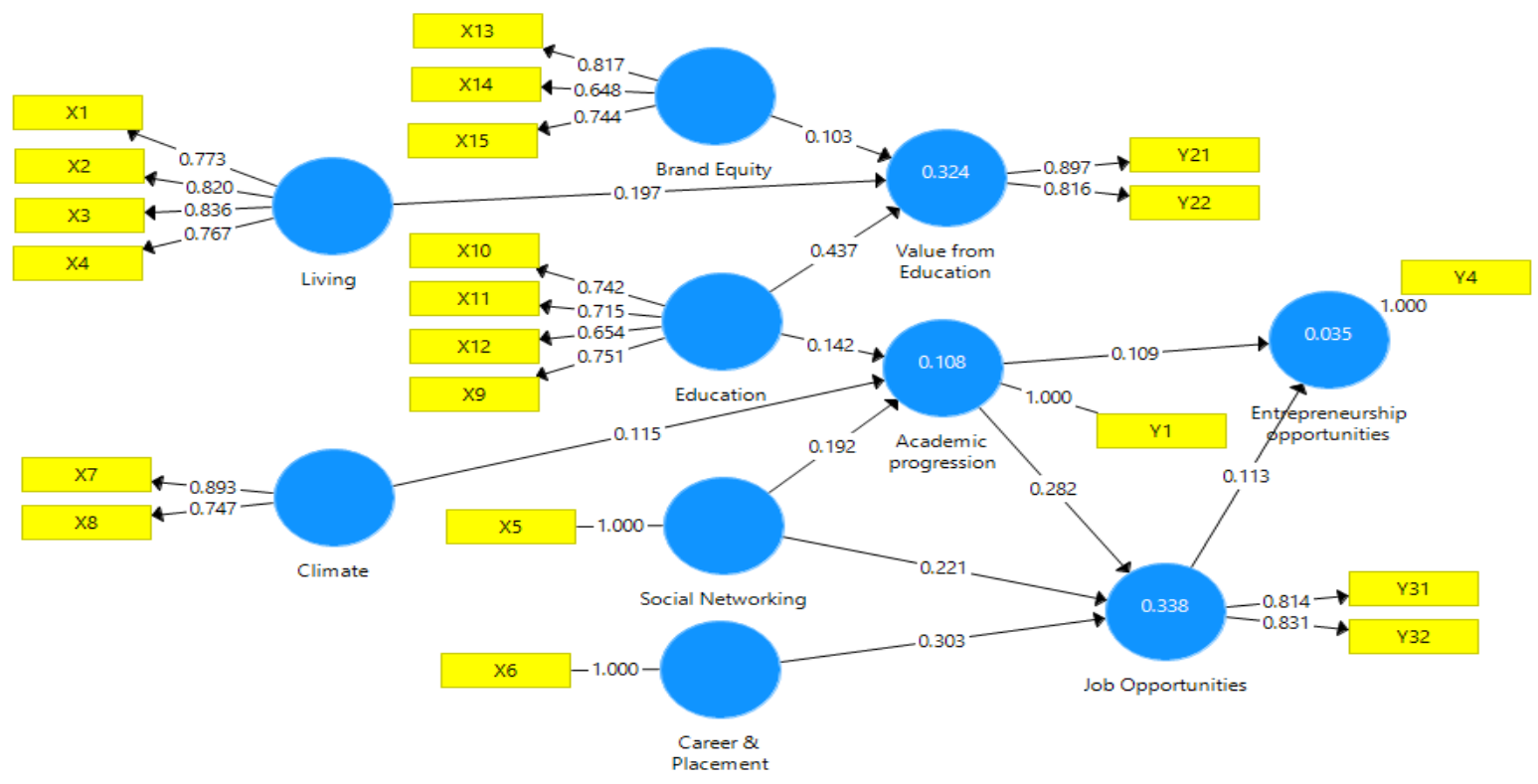


Reflective measurement model was assessed for composite reliability to evaluate internal consistency, individual indicator reliability and Average Variance Extracted (AVE) to evaluate convergent validity. The composite reliability values are between 0.7 and 0.9 which can be considered as satisfactory (Nunally and Bernstein, 1994). AVE for all constructs are above 0.5 indicating that there is satisfactory convergent validity on the latent variable level.

Table 6: Reliability and Convergent Validity of Measurement Model

\begin{tabular}{|l|r|r|r|r|}
\hline Constructs & \multicolumn{1}{l|}{$\begin{array}{l}\text { Cronbach's } \\
\text { Alpha }\end{array}$} & rho_A & $\begin{array}{l}\text { Composite } \\
\text { Reliability }\end{array}$ & $\begin{array}{l}\text { Average } \\
\text { Variance } \\
\text { Extracted } \\
\text { (AVE) }\end{array}$ \\
\hline Academic progression & 1 & 1 & 1 & 1 \\
\hline Brand Equity & 0.59 & 0.619 & 0.782 & 0.547 \\
\hline Career \& Placement & 1 & 1 & 1 & 1 \\
\hline Climate & 0.537 & 0.589 & 0.806 & 0.677 \\
\hline Education & 0.686 & 0.694 & 0.808 & 0.513 \\
\hline Entrepreneurship opportunities & 1 & 1 & 1 & 1 \\
\hline Job Opportunities & 0.523 & 0.524 & 0.807 & 0.677 \\
\hline Living & 0.812 & 0.819 & 0.876 & 0.639 \\
\hline Social Networking & 1 & 1 & 1 & 1 \\
\hline Value from Education & 0.645 & 0.675 & 0.847 & 0.735 \\
\hline
\end{tabular}

Discriminant validity has been examined using cross loadings (Table 7) and Fornell-Larcker criterion (Table 8).

Table 7: Cross Loadings

\begin{tabular}{|l|r|r|r|r|r|r|}
\hline CROSS LOADING & \multicolumn{7}{l|}{ Component } \\
\hline \multicolumn{1}{|l|}{} & $\mathbf{1}$ & $\mathbf{2}$ & $\mathbf{3}$ & $\mathbf{4}$ & $\mathbf{5}$ & $\mathbf{6}$ \\
\hline Indicators & $\mathbf{. 5 3}$ & -.149 & .117 & -.133 & -.052 & -.155 \\
\hline Accommodation is affordable & $\mathbf{. 7 9 4}$ & -.117 & .158 & -.012 & .029 & -.055 \\
\hline Accommodation is easily available & $\mathbf{. 7 3 4}$ & -.127 & -.041 & .125 & .052 & .072 \\
\hline $\begin{array}{l}\text { Adequate water is available for drinking \& domestic } \\
\text { purpose }\end{array}$ & & & & & & \\
\hline Better availability of quality and hygienic food & $\mathbf{. 6 5 0}$ & -.030 & .002 & .150 & .076 & -.047 \\
\hline Structure and construct of the course is of good standard & -.065 & $\mathbf{. 7 6 5}$ & -.091 & .047 & -.011 & -.034 \\
\hline Qualified Academic advisors are available & -.036 & $\mathbf{. 7 3 5}$ & .229 & .119 & -.274 & -.049 \\
\hline Quality of Education is better & -.133 & $\mathbf{. 6 7 4}$ & .101 & -.307 & .360 & -.138 \\
\hline There are more options for earning money during studies & -.346 & $\mathbf{. 6 0 0}$ & .130 & .018 & .184 & .005 \\
\hline
\end{tabular}




\begin{tabular}{|l|r|r|r|r|r|r|}
\hline Career information and placements are good & .055 & .065 & $\mathbf{. 6 7 2}$ & .062 & .128 & -.031 \\
\hline Climatic condition is conducive & -.064 & .021 & .018 & $\mathbf{. 7 3 1}$ & .226 & -.151 \\
\hline Climatic condition is good & -.122 & -.074 & .120 & $\mathbf{. 6 9 8}$ & .003 & .134 \\
\hline Better Social networking & .061 & -.191 & .311 & .103 & $\mathbf{. 6 8 7}$ & -.014 \\
\hline Strong alumni network & .033 & -.127 & .142 & -.050 & -.102 & $\mathbf{. 7 8 3}$ \\
\hline Good Brand name of the host city & -.140 & .050 & .108 & -.152 & .095 & $\mathbf{. 7 5 7}$ \\
\hline Recognized for the selected course of study & -.085 & .097 & -.114 & .246 & -.076 & $\mathbf{. 6 5 6}$ \\
\hline
\end{tabular}

Source: Factor analysis, SPSS output.

Table 7 shows the cross loadings of various items. The items loading on each construct is higher than the loadings on other constructs. Cross loadings are less conservative compared to FornellLarcker criterion (Hair, Ringle and Sarstedt, 2011). Table 8 indicates that the square root of AVE of a construct is greater than the correlation with any other construct. Thus the results from table 7 and 8 established discriminant validity.

Table 8: Fornell-Larcker criterion analysis

\begin{tabular}{|r|r|c|r|r|r|r|r|r|r|r|}
\hline & \multicolumn{1}{c|}{ AP } & BE & \multicolumn{1}{c|}{ CP } & CL & ED & EO & JO & LI & SN & VE \\
\hline AP & $\mathbf{1}$ & & & & & & & & & \\
\hline BE & 0.055 & $\mathbf{0 . 7 3 9}$ & & & & & & & & \\
\hline CP & 0.218 & 0.171 & $\mathbf{1}$ & & & & & & & \\
\hline CL & 0.211 & 0.189 & 0.297 & $\mathbf{0 . 8 2 3}$ & & & & & & \\
\hline ED & 0.223 & 0.251 & 0.38 & 0.226 & $\mathbf{0 . 7 1 6}$ & & & & & \\
\hline EO & 0.155 & 0.154 & 0.154 & 0.146 & 0.263 & $\mathbf{1}$ & & & & \\
\hline JO & 0.408 & 0.055 & 0.442 & 0.272 & 0.299 & 0.157 & $\mathbf{0 . 8 2 3}$ & & & \\
\hline LI & 0.191 & 0.329 & 0.321 & 0.341 & 0.274 & 0.156 & 0.243 & $\mathbf{0 . 8}$ & & \\
\hline SN & 0.271 & 0.199 & 0.353 & 0.335 & 0.284 & 0.162 & 0.405 & 0.366 & $\mathbf{1}$ & \\
\hline VE & 0.246 & 0.278 & 0.281 & 0.248 & 0.517 & 0.209 & 0.2 & 0.351 & 0.245 & $\mathbf{0 . 8 5 7}$ \\
\hline
\end{tabular}

The structural model is assessed for collinearity using the Variance Inflation Factor (VIF) criterion. Table 9 shows that the VIF values between the constructs are lesser than 5. This indicates there is no collinearity issue between predictor constructs.

Table 9 : Variance Inflation Factor (VIF)

\begin{tabular}{|c|c|c|c|c|c|c|c|c|c|c|}
\hline & AP & BE & CP & CL & ED & EO & JO & LI & SN & VE \\
\hline AP & & & & & & 1.199 & 1.1 & & & \\
\hline BE & & & & & & & & & & 1.158 \\
\hline CP & & & & & & & 1.164 & & & \\
\hline
\end{tabular}




\begin{tabular}{|c|c|c|c|c|c|c|c|c|c|c|} 
CL & 1.15 & & & & & & & & & \\
\hline ED & 1.111 & & & & & & & & & 1.116 \\
\hline EO & & & & & & & & & & \\
\hline JO & & & & & & 1.199 & & & & \\
\hline LI & & & & & & & & & & 1.173 \\
\hline SN & 1.187 & & & & & & 1.196 & & & \\
\hline VE & & & & & & & & & & \\
\hline
\end{tabular}

Bootstrapping, a process of drawing a large number of subsamples with replacement, was conducted with 5000 bootstrap samples with no sign changes. The path coefficients are provided in the figure 6.

Figure 6: Path coefficients from bootstrapping process

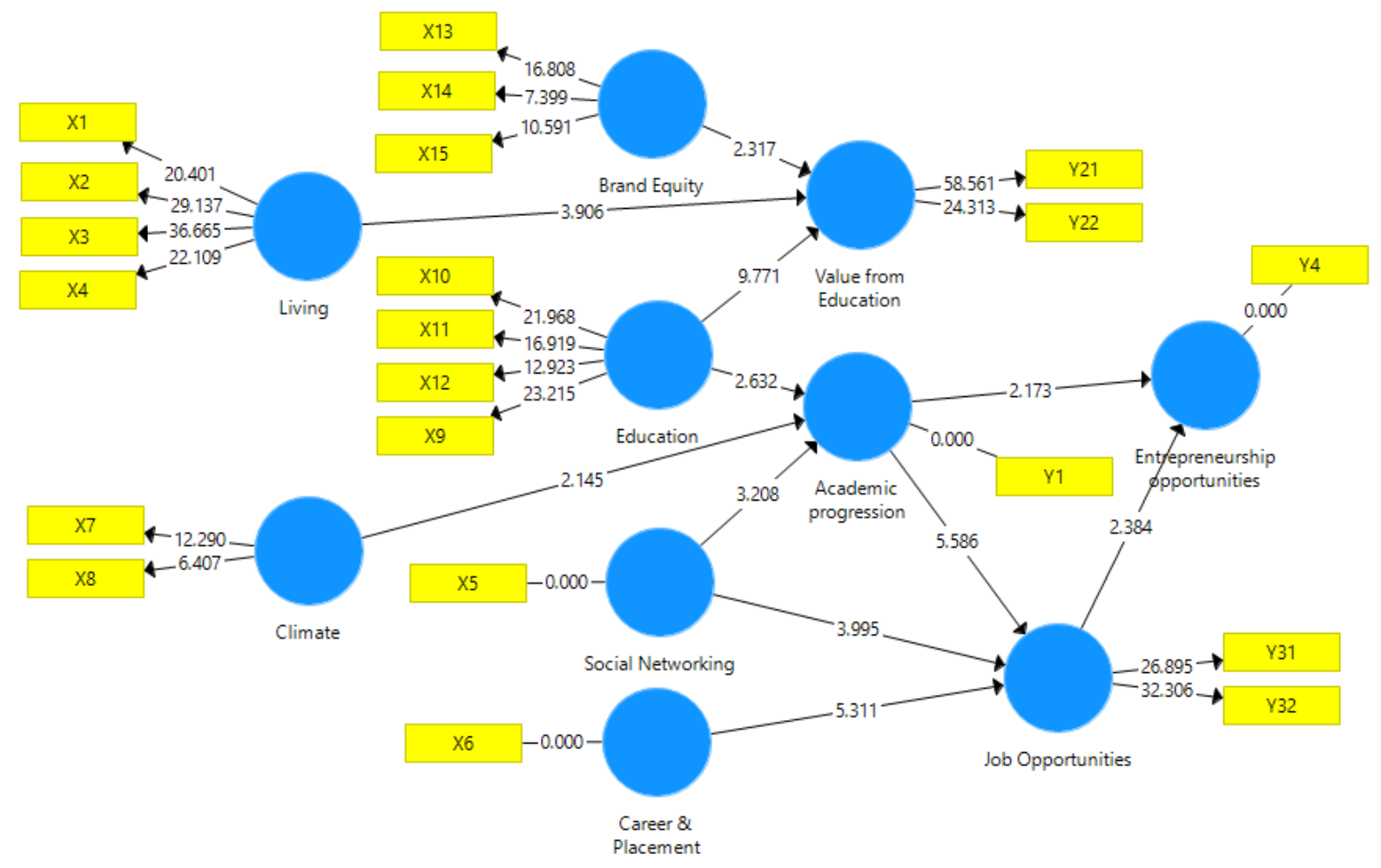

Table 10 shows the empirical t-statistic for various path coefficients. It is observed that AP -> $\mathrm{EO}, \mathrm{BE}->\mathrm{VE}, \mathrm{CL}>\mathrm{AP}, \mathrm{JO}->\mathrm{EO}$ are significant at $5 \%$ level and $\mathrm{AP}>\mathrm{JO}, \mathrm{CP}$-> JO, ED -> AP, ED -> VE, LI -> VE, SN -> AP and SN-> JO are significant at 1\%, thus all the hypotheses are supported and shows that there is positive effect between constructs as indicated in Table 11. 
Table 10: Estimation of path coefficient significance

\begin{tabular}{|l|c|c|r|r|r|}
\hline & $\begin{array}{c}\text { Original } \\
\text { Sample } \\
(\mathbf{O})\end{array}$ & $\begin{array}{c}\text { Sample } \\
\text { Mean } \\
(\mathbf{M})\end{array}$ & $\begin{array}{c}\text { Standard } \\
\text { Deviation } \\
\text { (STDEV) }\end{array}$ & $\begin{array}{c}\text { T Statistics } \\
(\mid \mathbf{O} / \text { STDEV })\end{array}$ & \multicolumn{1}{|c|}{ P Values } \\
\hline AP -> EO & 0.109 & 0.132 & 0.05 & 2.173 & 0.03 \\
\hline AP -> JO & 0.282 & 0.283 & 0.05 & 5.586 & 0 \\
\hline BE -> VE & 0.103 & 0.108 & 0.045 & 2.317 & 0.021 \\
\hline CP > JO & 0.303 & 0.303 & 0.057 & 5.311 & 0 \\
\hline CL -> AP & 0.115 & 0.122 & 0.054 & 2.145 & 0.032 \\
\hline ED -> AP & 0.142 & 0.144 & 0.054 & 2.632 & 0.009 \\
\hline ED -> VE & 0.437 & 0.439 & 0.045 & 9.771 & 0 \\
\hline JO -> EO & 0.113 & 0.115 & 0.047 & 2.384 & 0.017 \\
\hline LI -> VE & 0.197 & 0.2 & 0.051 & 3.906 & 0 \\
\hline SN -> AP & 0.192 & 0.19 & 0.06 & 3.208 & 0.001 \\
\hline SN-> JO & 0.221 & 0.221 & 0.055 & 3.995 & 0 \\
\hline
\end{tabular}

Table 11: Hypotheses test results

\begin{tabular}{|l|l|l|c|}
\hline \multicolumn{1}{|c|}{ Path } & \multicolumn{1}{|c|}{ Hypotheses } & \multicolumn{1}{|c|}{$\begin{array}{c}\text { P } \\
\text { Values }\end{array}$} & $\begin{array}{c}\text { Hypotheses } \\
\text { support }\end{array}$ \\
\hline AP -> EO & $\begin{array}{l}\text { H1: Living conditions during education has a positive effect on Value } \\
\text { derived from Education }\end{array}$ & 0.030 & Yes \\
\hline AP -> JO & $\begin{array}{l}\text { H2: Conducive climatic conditions during education has a positive effect } \\
\text { on academic progression }\end{array}$ & 0.000 & Yes \\
\hline BE -> VE & H3: Brand Equity has a positive effect on Value from Education & 0.021 & Yes \\
\hline CP -> JO & $\begin{array}{l}\text { H4: Quality and Structure of Education has a positive effect on Value } \\
\text { from Education }\end{array}$ & 0.000 & Yes \\
\hline CL -> AP & $\begin{array}{l}\text { H5: Quality and Structure of Education has a positive effect on academic } \\
\text { progression }\end{array}$ & 0.032 & Yes \\
\hline ED -> AP & H6: Social Networking has a positive effect on Academic progression & 0.009 & Yes \\
\hline ED -> VE & H7: Social Networking has a positive effect on Job opportunities & 0.000 & Yes \\
\hline JO -> EO & $\begin{array}{l}\text { H8: Career \& placements activities has a positive effect on Job } \\
\text { opportunities }\end{array}$ & 0.017 & Yes \\
\hline LI -> VE & H9: Academic progression has a positive effect on Job opportunities & 0.000 & Yes \\
\hline SN -> AP & $\begin{array}{l}\text { H10: Academic progression has a positive effect on Entrepreneurship } \\
\text { opportunities }\end{array}$ & 0.001 & Yes \\
\hline SN-> JO & $\begin{array}{l}\text { H11: Job opportunities has a positive effect on Entrepreneurship } \\
\text { opportunities }\end{array}$ & 0.000 & Yes \\
\hline
\end{tabular}

The predictive accuracy of the proposed PLS-SEM of student migration was assessed using the coefficient of determination $\left(\mathrm{R}^{2}\right)$. For researches related to social science, $\mathrm{R}$ squared value of 
0.20 and above are considered high. According to Cohen (1998), for endogenous latent constructs, $\mathrm{R}$ squared values of 0.26 and above are considered substantial, 0.13 are moderate and 0.02 are weak. Table 12 indicates the R-squared values of the endogenous constructs of the proposed PLS-SEM model.

Table 12: R2 and Adjusted R2 values for Endogenous constructs

\begin{tabular}{|l|c|c|}
\hline & R Square & $\begin{array}{c}\text { R Square } \\
\text { Adjusted }\end{array}$ \\
\hline Academic progression & 0.108 & 0.101 \\
\hline Entrepreneurship opportunities & 0.035 & 0.029 \\
\hline Job Opportunities & 0.338 & 0.332 \\
\hline Value from Education & 0.324 & 0.319 \\
\hline
\end{tabular}

The $\mathrm{R}^{2}$ values of Job opportunities and Value for Education (endogenous constructs) are above 0.26 indicating that the combined effect of exogenous latent variables on these endogenous constructs are substantial. Latent Variable 'Academic progression' R squared value indicates near moderate effect while Entrepreneurship opportunities R squared value indicate weak effect from the exogenous latent variables.

The f square, that is the size effect of the omitted latent constructs on the endogenous variables, are provide in Table 13. The values of0.02, 0.15, and 0.35, respectively, represent small, medium, and large effects (Cohen, 1988) of the exogenous latent variable. The Table 13 shows that only Education Construct has a medium effect on value for education (0.254).

Table 13: Size Effect of exogenous constructs

\begin{tabular}{|c|c|c|c|c|c|c|c|c|c|c|}
\hline & AP & BE & CP & CL & ED & EO & JO & LI & SN & VE \\
\hline AP & & & & & & 0.01 & 0.109 & & & \\
\hline BE & & & & & & & & & & 0.014 \\
\hline CP & & & & & & & 0.119 & & & \\
\hline CL & 0.013 & & & & & & & & & \\
\hline ED & 0.02 & & & & & & & & & 0.254 \\
\hline EO & & & & & & & & & & \\
\hline JO & & & & & & 0.011 & & & & \\
\hline LI & & & & & & & & & & 0.049 \\
\hline SN & 0.035 & & & & & & 0.062 & & & \\
\hline VE & & & & & & & & & & \\
\hline
\end{tabular}




\section{Discussion}

Students migrate to Karnataka for higher education, majorly for reasons like better job and entrepreneurship opportunities and ability to progress further in academics. In this paper, an exploratory factor analysis was conducted to identify the latent variables from the responses collected through a questionnaire. Based on the factors of reliability, exogenous latent variables like living conditions, education, career and placement, climate, social networking and brand equity and endogenous latent factors like value for education, academic progression, entrepreneurship and job opportunities were used to construct a reflective PLS-SEM. PLS-SEM shows the path effects among various constructs to support the hypotheses.

The exogenous and endogenous variables identified under this study shows that the various factors which influence migration of the students are basically classified into pull factors of the geographic location like the living conditions and climatic conditions; those factors relating to the educational institution like the quality of education, the career and placement services, the opportunity to network and brand image of the institution and finally the factors which are important for one's own personal career development like the academic progression, entrepreneurship and job opportunities available after the education.

On a sample size of 352 responses, a PLS-SEM algorithm was run using a path weighting scheme with 300 iterations. The indicator reliability and validity were tested. The results of the hypotheses test support all the proposed hypotheses.

Hypotheses 1, 3 and 4 shows that, the living conditions during the education, the brand equity of the institution, as well as the quality and structure of the education has a positive effect on the value derived from the education for a migrant student. 'Value from education' indicators are 'increase in the status and prestige', as well as 'the ability to earn higher than the education expenses'. As, Indian Philosopher, Vivekananda said 'Education is the manifestation of perfection already in man', any education has to give the required value to manifest the full potential of the student. The value comes from the class rooms, the institution and the whole ecosystem of the city and the state in which student pursue the education.

From the results of hypotheses (1,3 and 4), it is argued that the brand equity of the 'place of education' and institutions has a direct influence on the status and prestige of the student as well 
as his ability to earn a higher income after his education. It becomes important for universities to understand the brand's meaning on the overall perceptions of the students. From the students' perspective, branding works as an assurance in meeting their anticipations and aid judgments involving choice of which institute to join (Gupta \& Singh, 2010).

Recognizing that brand equity has an awareness dimension, it is argued that awareness is largely driven by marketing activities including advertising and publicity. Branding has increasingly become a strategic imperative for universities and other post-compulsory educational institutions in order to develop meaningfully differentiated brands to communicate their strengths (Jevons, 2006).

The living conditions which includes the accommodation, affordability, quality of water and food which are part of the expenses that the student incur during the education has a direct influence on determining whether the return on investment during education will be higher or lower, based on the salary earned after the education. In this regard, the role of the government is also important because the brand of the city is a significant factor to attract migrant students for education and that the living conditions specific to the city are major influencing factors. The brand image of the city is based on the city's reputation for its infrastructure facilities, cost of living and the opportunities it can provide after education. For this, the government's policies and implementations on city development and education system become very crucial. The Silicon Valley of India and the startup capital of the country Karnataka, would provide an ideal platform for any student to pursue higher education. This eco-system not only prepares them for corporate career but also prepares them to excel in the competitive world and to become a lifelong learner. As rightly said 'education is that what one remembers after forgetting what is taught in the class'.

The 'Structure of the education' indicated by the qualified academic advisors, quality of education, the structure of the course and earning opportunities during studies can also be beneficial and have a positive influence on migration studies. A good structured course and qualified advisors in the institution (like professors, career counselors) will help the student to improve abilities and skill sets to get a better job with a higher salary. Experiential learning is another ingredient of a good education system. Higher education institutions in Karnataka have 
realized this and they have emerged as most sought-after institutions for higher education in India.

Thus, if an education institution is looking for attracting students from outside the state it will have to focus on these three aspects which are to provide better hostel and accommodation facilities, to provide better quality and structured education with highly qualified academic instructors, as well as to make sure that a strong brand image through good alumni networking is built.

In an increasingly competitive higher education sector, universities face significant challenges when it comes to recruiting new students (Bock, Poole, \& Joseph, 2014; Joseph, Mullen, \&Spake, 2012). Networking for students is crucial as it helps students to exchange ideas. Through this platform they can remain updated on latest changes and current affairs in their interested areas. Networking gives visibility to the students and it also opens up opportunities in terms of career and self-development.

Universities' positioning strategies may be focusing too much on building prestige, whereas strategies aimed at improving student satisfaction could have more positive effects on 'brand equity'. Universities must dedicate to "degree quality and quality of staff”. Universities always must zone in on the individual student's experience to enhance their attachment to the brand.

A study by Gatfield et al. (1999) shows that recognition (quality of teachers and resources), campus life (added features), and guidance (access services) are the most salient promotional features used in marketing universities. In related research, Gray et al. (2003) identify a university's learning environment, reputation, graduate career prospects, destination and cultural integration as the main brand positioning dimensions for higher education institutions. Black (2008) specifically addresses the concept of brand promise and "the role of all faculty, staff, and administrators as 'institutional trust agents' in the delivery of the promise.

The role of faculty and staff in creating a university brand cannot be overstated. Whisman (2009, p. 368) puts it well when he writes, "Like their corporate counterparts, colleges and universities must recognize that their most valuable tangible asset is their passionate employees."

Ivy (2008) identifies seven distinct factors that students find important in the selection of a university business school. In order of importance, with most important first, the factors are the 
program (choice of majors, electives), prominence (reputation), price (tuition), prospectus (communication through direct mail), people (interactions with faculty, staff, and other students), promotion (publicity and e-media), and premiums (mixture of various offerings)

With respect to brand positioning, the prior research (Gatfield et al., 1999; Gray et al., 2003; Mazzarol, 1998) has identified academic instruction and learning environment, campus life, reputation, and career prospects for graduates as being the most salient dimensions in higher education. Not surprisingly, perceived quality (primarily as manifested by the courses offered) and reputation of an institution are among the strongest influences on student choice of institution (Chen \& Hsiao, 2009; Mazzarol \& Soutar, 2002; Wilkins \& Huisman, 2011).

From the study, academic and career progression is identified as the other two important factors which are influencing the student's migration to Karnataka. Academic progression is a continuous process of connecting theory to practice, connecting elementary to advanced and nurturing multidisciplinary education. This is possible in Karnataka because of hard and soft infrastructure, multi-cultural environment, peer support and advanced industry institution interface.

The hypotheses $2,5 \& 6$, support the argument that the quality of the Education and social networking are important for academic progression. 'Academy progression' in this research is nothing but the students staying back in the same city and/or institution for continuing their education. The indicator 'good and conducive climatic conditions' indicate to have a positive influence on the student staying back for academic progression. The quality of education received, availability of qualified advisors and the structure of the course, along with the social networking factors have a positive effect on the students' academic progression. Thus the results of these hypotheses provide additional evidence to corroborate the fact discussed earlier that the student migrate to a specific city or an educational institution if

1. The institution has a strong alumni network and well qualified academic professors/advisors.

2. The quality and the structure of the course is a high standard coupled with lower cost living. 
PLS-SEM model constructed in this paper provide evidence to support that the students migrate for job opportunities. While academic progression, social networking and careers and placement services have a direct influence on the 'job-opportunities', the quality of education has an indirect influence on the student's job opportunities. This is shown under the hypotheses 7, 8 and 9.

Though there is support to hypotheses 10 and 11 relating to the student migration influenced by entrepreneurship opportunities, the adjusted $\mathrm{R}$ squared indicate weak effects with this regard. Perhaps this may be a significant result because most of the educational institutions in Karnataka are focused on providing technical education and are not focused on providing entrepreneurial education. Almost every business management courses are also mostly focused on providing the students with skills required to become a manager rather than to become an entrepreneur. This result, could also be reflective of the fact that the Government of Karnataka is not investing in entrepreneurship promotion activities and undertaking necessary policies to attract migrant students with an objective of becoming an entrepreneur. The study provides an indication that the students migrate to Karnataka mostly for academic progression and for job opportunities, rather than to set up their own ventures after higher education.

From the analysis of the results it can thus be concluded that the various pull factors for student migration to Karnataka for Higher Education indicate the purpose of seeking better jobs or to continue their higher education. Even though Karnataka is a growing economic hub the paper established only a weak relationship between student migration to Karnataka for entrepreneurship. There is further scope for research to identify the factors behind this weak relationship.

\section{Conclusion}

This study would enable institutions to understand what makes Karnataka a destination in demand for higher education. The factors derived from this study can be nurtured to make institutions better and more institutions can join the elite group of institutions, so that Karnataka can retain and sustain the leadership position in the higher education in the country. With changing times the priorities and expectations of the students keeps changing. New Delhi and Maharashtra are competing with Karnataka to attract students from different parts of the country. 
In this background, institutions, government and educationists have to awaken to the need and the study would be a pointer towards this.

The student migration for higher education is motivated by factors which are beyond the bounds of gaining education. The prospect of better career and job prospects compel them to migrate to destinations which provide these opportunities. Brain drain leading to regional economic imbalances is the direct consequence of such migration. Thus, this paper provides insight to policy makers to identify factors which can maintain this balance.

\section{References}

Abbott, W .F. and C.F. Schmid(1975), university prestige and first time undergraduate migration in the united states, Sociology of education , 48(2), 168-185

Asif Ishtiaque, Md. Sofi Ullah(2013), The influence of factors of migration on the migration status of rural-urban migrants in Dhaka, Bangladesh, Journal of Studies and Research in Human Geography ,7(2), 45-52

Barclay, D. W.,Higgins, C. A., \& Thompson, R. (1995), The partial least squares approach to causal modeling: P ersonal computer adoption and use as illustration. Technology Studies, 2, 285-309

Baharun, R., Awang, Z., \&Padlee, S.F. (2011), International students' choice criteria for selection of higher learning in Malaysian private universities, African Journal of Business Management, 5, 4704-4714

Bayer,A.E.,( 1968) ,Interregional migration and education of American scientists, Sociology of education,41(1),88-102

Bezmen T. \&Depken C. A. (1998), School characteristics and demand for college. Economics of Education Review, 17, 205-210

Black, J. (2008, January). The branding of higher education, http://www.semworks.net/papers/wp-The-Branding-of-Higher-Education.html, (accessed 16 October 2009).

Black, R., D. Kniveton and K. Schmidt-Verkerk, (2011), Migration and Climate Change: Towards an Integrated Assessment of Sensitivity ,Environment and Planning, 43

Braxton, J.M. (1990), How Students Choose Colleges. In D. Hossler\& J. Bean \& Associates (Eds.), The strategic management of college enrollments (57-67), San Francisco CA: JosseyBass

Carbone R .F .(1973), The future of the low tuition system, Educational record, 54(4), 265-270 
Ciriaci, D. \&Muscio, A. (2011), University choice, research quality and graduates' employability: Evidence from Italian national survey data. AlmaLaurea Working Papers, 49, 114

Chhapial, Hemali(2014), 37 lakh migrated for education within India in a decade, http://timesofindia.indiatimes.com/home/education/news/37-lakh-migrated-for-education-withinIndia-in-a-decade/articleshow/29729578.cms

Christal , M.E.( 1982), The sweep the south :Fact and fallacy, presented at Annual conference of the southern association for institutional research, Birminhham, Alabama

Cohen, J. (1988), Statistical power analysis for the behavioral sciences (2nd ed.). Hillsdale, NJ: Lawrence Earlbaum Associates

Creswell, J. W., \& Plano Clark, V. L. (2006). Designing and Conducting Mixed Methods Research. Thousand Oaks, CA: Sage.

D.E. Bock, S.M. Poole, M. Joseph (2014), Does branding impact student recruitment: A critical evaluation, Journal of Marketing for Higher Education, 24 (1), 11-21

Edward A. Baryla, Jr. \& Douglas Dotterweich (2001), Student Migration: Do Significant Factors Vary by Region?, Education Economics, 9(3)

Fenske R.H., C.S Scott and J.F.carmody (1973), Recent trends in studies of student migration, Journal of Higher education, 45(1), 61-74

Ferris.L., (1973), Higher educational institutions and the migration talent, collefe and University,49(1),19-29

Gatfield, T, Braker, B., \& Graham, P. (1999), Measuring communication impact of university advertising materials, Corporate Communications: An International Journal, 4 (2), 73-79.

Gilbert A. Churchill (2009), Marketing Research: Methodological Foundations, 10th edition, South-Western College Pub

Gossman .S et al (1968), Migration of college and university students in the United States, Seattle, University of Washington press

Gray, B. J., Fan, K. S., \& Llanes, V. A. (2003), Branding universities in Asian markets, Journal of Product \& Brand Management, 12 (2/3), 108-112.

Gries Thomas, Manfred Kraft, Christina Pieck (2011), Interregional migration, self-selection and the returns to education in Brazil, The Annals of Regional Science , 46(3), 707-732

Gupta, M. \& Singh, P.B. (2010). Marketing and branding higher education, Issues and challenges. Review of Business Research, 10(1), 46-53.

Hair, J. F., Ringle, C. M., \&Sarstedt, M. (2011), PLS-SEM: Indeed a silver bullet. Journal of Marketing Theory and Practice, 19, 139-151 
Henseler J (2010), On the convergence of the partial least squares path modeling algorithm.

Comput Stat , 25(1), 107-120

Isherwood G. B. (1991), College choice: A survey of English-speaking high school students in Quebec. Canadian Journal of Education, 16, 72-81

Ivy, J. (2008). A new higher education marketing mix: The 7Ps for MBA marketing. International Journal of Educational Management, 22 (4), 288-299.

Joseph F. Hair, Jr., G.Tomas M. Hult, Christian M. Ringle, Marko Sarstedt (2014), A Primer on Partial Least Squares, SAGE publication

Joseph, M. B. \& J. B. Ford. (1997), Importance-performance analysis as a strategic tool for service marketers: The case of service quality percept- ions of business students in New Zealand and the USA. The Journal of Services Marketing, 13, 171-186.

Keskinen E., Tiuraniemi J., \&Liimola A. (2008), University selection in Finland: how the decision is made. International Journal of Educational Management, 22, 638-650

Kusumawati, A., Yanamandram, V. K. \&Perera, N. (2010), Exploring Student Choice Criteria for Selecting an Indonesian Public University: A Preliminary Finding

Kyaing Kyaing Thet (2014), Pull and Push Factors of Migration: A Case Study in the Urban Area of Monywa Township, Myanma, News from the world of statistics, 1(4), http://www.worldofstatistics.org/files/2014/03/March-24-2014.pdf

Lankford, F. G., Jr. and A. L. Taylor (1971), "College and University Student Migration: The Case of Virginia," University of Virginia Newsletter, 47(5) , 17-20.

Lee ES, (1966), A Theory of Migration. Demography, 3(1), 47-57

Mazzarol, T. (1998). Critical success factors for international education marketing. International Journal of Education Management, 12 (4), 163-175.

Mazzarol and Soutar (2002), Push-pull' factors influencing international student destination choice, International Journal of Educational Management, 16 (2) ,82-89

M. Joseph, E.W. Mullen, D. Spake(2012), University branding: Understanding students' choice of an educational institution, Journal of Brand Management, 20 (1), 1-12

McLaughlin, D.K., and L. Perman (1991), Returns vs. Endowments in the Earnings Attainment Process for Metropolitan and Nonmetropolitan Men and Women, Rural Sociology, 56, 339-65

Mills, B.F., and G. Hazarika (2001), Migration of Young Adults from Non-Metropolitan Counties, American Journal of Agriculture Economics, 83, 329-40

Nunally, J. C., \& Bernstein, I. (1994), Psychometric theory. New York: McGraw-Hill

Paulsen, M. (1990), College choice: Understanding student enrollment behavior. Washington, D.C.: Eric Clearinghouse on Higher Education and George Washington University 
Perch-Nielsen, S., Bättig, M., and Imboden, D. (2008), Exploring the link between climate change and migration. Climatic Change, 91(3-4), 375-393

Ravenstein EG (1885), The Law of Migration, Journal of the Statistical Society of London, 48(2), 167-235

Rushton, J. P. and S. Meltzer (1981), Research Productivity, University Revenue, And Scholarly Impact (Citations) Of 169 British, Canadian And United States Universities (1977),Scientometrics, 3(4), 275-303.

S Chandrasekhar and Sharma, Ajay (2014), Internal Migration for Education and Employment among Youth in India,WP-2014-004 Indira Gandhi Institute of Development Research, Mumbai

Sidin, S., Hussin, S. \& Soon, T. (2003), An exploratory study of factors influencing the college choice decision of undergraduate students in Malaysia. Asia-Pacific Management Review, 8, 259-280

Soutar G. N. \& Turner J. (2002), Students' preferences for university: a conjoint analysis. The International Journal of Educational Management, 16, 40-45

Steve Chapman \& Patrick McNeill (2005), Research Methods, Taylor \& Fransis publication

Tang T.L., Tang D.S., Tang C.S. (2004), College tuition and perceptions of private universityquality, International Journal of Educational Management, 18, 304-316

University Brand Equity: An Empirical Investigation of its Dimensions (PDF Download Available). Available from:

https://www.researchgate.net/publication/267625843_University_Brand_Equity_An_Empirical_ Investigation_of_its_Dimensions [accessed Jan 10 2018].

Veena A and K Rao, Sandeep. (2017), Analysis of Socio Economic Conditions and Migration Patterns of Migrant Settlements in Bengaluru, Shinoda, Inoue and Suda (eds), Social Transformation and Cultural Change in South Asia: From the Perspectives of the SocioEconomic Periphery, ISBN 978-4-904626-27-6, (pp. 141-164), Tokyo: The Institute of Oriental Studies, Daito Bunka University

Vries J, Nijkamp P, Rietveld P (2000), Alonso's General Theory of Movement, Tinbergen Institute Discussion Paper (TI 2000-062/3)

S. Wilkins, J. Huisman(2011), Student recruitment at international branch campuses: Can they compete in the global market?, Journal of Studies in International Education, 15 (3), 299-316

Y.F. Chen, C.H. Hsiao(2009), Applying market segmentation theory to student behavior in selecting a school or department ,New Horizons in Education, 57 (2) , 32-43

Whisman, R. (2007). Internal branding: A university's most intangible asset. Journal of Product \& Brand Management, 18 (5), 367-370. 